\title{
Evaluation of eugenol as anesthetic in Cat-fish (Clarias gariepinus) with special reference to biochemical and histopathological alterations
}

\author{
M. A. F. Abdel-Fattah ${ }^{1}$, Amina A. Dessouki², \\ T. Ramadan ${ }^{3}$, Mona M. Ismail ${ }^{4}$ \\ Departments of ${ }^{1}$ Pharmacology, ${ }^{2}$ Pathology ${ }^{3}$ Clinical Pathology and ${ }^{4}$ Fish Diseases and Management, Faculty \\ of Veterinary Medicine, Suez Canal University, Ismailia, Egypt
}

\begin{abstract}
The anesthetic, biochemical and pathological effects of eugenol were evaluated in the African cat-fish Clarias gariepinus in comparison with MS-222. Aquous exposure of Clarias gariepinus to eugenol at concentration of $62.5-250 \mu \mathrm{g} / \mathrm{ml}$ showed short interval to induction than MS-222. On the other hand, eugenol provided longer time for recovery $(8.28 \mathrm{~min})$ at higher concentration $(250 \mu \mathrm{g} / \mathrm{ml})$ than MS-222 $(5.26 \mathrm{~min})$ but no differences were observed at lower concentrations between both agents. Mortality rate of 46.5 and $33.3 \%$ was recorded for eugenol and MS-222, respectively at $250 \mu \mathrm{g} / \mathrm{ml}$. Exposure of fish to $250 \mu \mathrm{g} / \mathrm{ml}$ of eugenol or MS-222 resulted in significant increases in serum levels of creatinine, urea and uric acid and decrease in total protein and albumin. Significant increases in AST, ALT and Ca levels were recorded only on exposure to eugenol $250 \mu \mathrm{g} / \mathrm{ml}$. Histopathological examinations showed congestion of gill blood vessels, diffuse vacuolar degeneration and necrosis of the epithelium lining of the secondary lamellae of the gill filaments, degeneration and focal necrosis of renal tubules in kidneys, necrosis and deposition of hemosiderin pigment in the macrophages of spleen which is indicative for hemorrhages and hemolysis as well as mild catarrhal enteritis of intestine of fish groups exposed to 250 $\mu \mathrm{g} / \mathrm{ml}$ of both agents. Moreover, massive fatty and degenerative changes in liver were observed only in fish exposed to $250 \mu \mathrm{g} / \mathrm{ml}$ of eugenol. On the other hand, lower concentrations of both agents did not differ from those of control fish. In conclusion, it appears that eugenol at lower and medium concentrations could produce an anesthesia characterized by rapid induction and rational recovery without significant changes in tissues and blood chemistry. Care should be taken on using high concentrations of eugenol as ventilatory failure may occur.
\end{abstract}

Anesthesia in fish is of great importance either in field or in laboratory for minimizing stress conditions facing fish on tagging, measuring body weight and length, taking blood samples, during transportation of live fish and surgical operations. MS-222 is the most commonly used fish anesthetic approved by FDA in food fish. It should be used with caution in saltwater fish and a withdrawal period of 21 days is required before fish can be consumed by humans Booth and McDonald, (1986). Since, all forms of chemical anesthesia are known to alter body biochemistry resulting in disturbances of physiological function, subtle behavioral and immunological effects Blaxter and Tytler, (1978) and Mattson, and Riple, (1989). Recently, the efforts are directed towards the search for safer and less expensive anesthetic. The cost of clove oil relative to MS-222 and the extensive testing and use in dentistry Virapin,
(1968) and as a food ingredient makes it an attractive candidate as a fish anesthetic. Eugenol represents $85-95 \%$ of clove oil. It exists as a natural constituent of many plant essential oils such as clove (Eugenia caryophyllata), Artemesia dracunculus Meepagala et al., 2002, Ocimum basilicum Miele et al., 2001 and Myresitica fragans (Sell and Carlini, 1976). Who introduced Eugenol for mammals? Recently, Sladky et al., 2001 demonstrated that eugenol is an effective immobilization compound in red pacu (Piaractus brachypomus). To anesthetize fish, firstly, we should look to the side effect of the different drugs used with special attention to the tissue damage occurred in the vital organs. However, the potential of eugenol to cause disturbances in blood biochemistry and tissues injury has not been investigated. So, this study was conducted to evaluate eugenol as anesthetic in Clarias gariepinus and to identify the 
biochemical and pathological changes following its administration in comparison with MS-222.

\section{Materials and Methods}

Fish. Apparently healthy cat-fish (Clarias gariepinus) were kept in fully prepared glass aquaria $(80 \times 50 \times 40 \mathrm{~cm})$. They were supplied with chlorine free tap water according to what is previously described by Innes, (1966). Continuous aeration was maintained in each aquarium using electric air pumping compressors (Rina, Italy). Water temeprature was controlled at $25 \pm 1{ }^{\circ} \mathrm{C}$ using thermostatic heaters (type CMI, Germany).

Drugs. Eugenol, (4-allyl-2-methoxy-phenol, 99.9\%) was obtained from Wako Pure Chemical Industries, Ltd, Japan. As it is poorly soluble in water, dimethyl sulphoxide (DMSO) was chosen as its solvent. A $10 \% \mathrm{v} / \mathrm{v}$ solution in DMSO was prepared and used as the original solution in this study. Tricaine methanesulfonate (MS-222) was obtained from Argent Laboratories. All chemicals were given by aqueous exposure.

Experimental design. One hundred and five $C$. gariepinus of average body weight $150 \pm 10 \mathrm{gm}$ were classified into 7 equal groups 15 fish of each. The first, second and third groups were exposed to eugenol at concentrations of 250, 125 and 62.5 and $\mu \mathrm{g} / \mathrm{ml}$, respectively. Fish in the fourth, fifth and sixth groups were exposed to MS-222 at concentrations of 250, 125 and 62.5 $\mu \mathrm{g} / \mathrm{ml}$ respectively. Fish in the seventh groups were left as non-treated control group.

Monitoring of anesthesia. When fish were placed into aquaria in which tested chemicals were dissolved, the induction period (time elapsed from drug application till loss of tail reflex) and recovery period (time elapsed from removal of fish from medicated water to clean water till it become active and balance her self in aquaria) were calculated. In addition, tail reflex was scored according to the method of Bell, (1967) as (-) completely lost, (+) moderately lost, (++) mildly lost and $(+++)$ completely present. Mortality rate within 24 hours was recorded. Blood samples were obtained during full anesthesia by puncturing the caudal vein and centrifuged at $3000 \mathrm{rpm}$ for $20 \mathrm{~min}$ for obtaining clear serum.

Biochemical analysis. The obtained serum was used for estimating the activity of serum aspartate aminotransferase (AST) and serum alanine aminotransferase (ALT) according to the method of Reitman and Frankel, (1957). Serum total protein was measured according to the method described by Henry, (1974) and serum albumin was measured according to the method of Doumas, (1971) whereas serum globulin was calculated by substraction of the obtained albumin level from the level of total protein as described by Doumas and Biggs, (1972). Serum urea and uric acid were determined according to the method of Patton and Grouch, (1977) and serum creatinine was determined according to Henry, (1979) whereas serum calcium was determined according to Gundler and Kin, (1972).

Histopathological examination. Specimens (livers, spleens, gills, kidneys and intestines) were collected from fish 24 hours following exposure to anesthetics and fixed in $10 \%$ neutral buffered formalin. Fixed specimens were dehydrated in alcohol then clearing was performed in xylene, embedded in paraffin and $4-6 \mu \mathrm{m}$ paraffin sections were prepared. The sections were stained with hematoxylin and eosin as a routine stain according to Bancroft and Stevens, (1990).

\section{Results}

Anesthetic Effects of Eugenol and MS-222 in Clarias gariepinus. As shown in Table 1. Clarias gariepinus exposed to eugenol showed short interval to induction $(1.72,2.8$ and 4.95 $\mathrm{min})$ at concentration of 250,125 and $62.5 \mu \mathrm{g} /$ $\mathrm{ml}$ respectively, whereas MS-222 produced longer period of induction (2.5, 6.1 and $13.4 \mu \mathrm{g} /$ $\mathrm{ml})$ at the same concentration ranges. On the other hand, eugenol provides longer time for recovery ( $8.28 \mathrm{~min})$ at higher concentration (250 $\mu \mathrm{g} / \mathrm{ml}$ ) than MS-222 (5.26 $\mathrm{min})$ but no difference at the medium $(125 \mu \mathrm{g} / \mathrm{ml})$ and low $(62.5 \mu \mathrm{g} / \mathrm{ml})$ concentrations between eugenol (4.82 and 4.25) and MS-222 (4.12 and $2.18 \mathrm{~min}$ ) respectively (Table 1). Both eugenol and MS222 produced an anesthetic effect in a concentration-dependent manner. Tail and escape reflex were completely lost during anesthesia with both agents at higher concentration $(125-250 \mu \mathrm{g} / \mathrm{ml})$ and moderately lost at lower concentration. Mortality rate of 46.5 and $33.3 \%$ was recorded for eugenol and MS-222 at higher concentration $(250 \mu \mathrm{g} / \mathrm{ml})$ within 24 hours after administration but no mortalities were recorded at medium and low concentrations (Table 1). Biochemical changes induced by eugenol and MS-222 in Clarias gariepinus. Clarias gariepinus exposed to eugenol at high concentration $(250 \mu \mathrm{g} \mathrm{g} / \mathrm{ml})$ showed a significant increase in AST, ALT, creatinine, urea, uric acid and $\mathrm{Ca}$ levels and a significant decrease in total protein 
Table (1): Anesthetic parameters following eugenol and MS-222 application in Clarias gariepinus

\begin{tabular}{|c|c|c|c|c|c|c|}
\hline Treatment & Group & $\begin{array}{l}\text { Conc. } \\
(\mu \mathrm{g} / \mathrm{ml})\end{array}$ & $\begin{array}{c}\text { Induction } \\
\text { period (min) }\end{array}$ & $\begin{array}{c}\text { Recovery } \\
\text { period (min) }\end{array}$ & Tail reflex & $\begin{array}{c}\text { Mortality } \\
\text { rate }(\%)\end{array}$ \\
\hline \multirow{3}{*}{ Eugenol } & 1 & 250 & $1.72 *$ & $8.28 *$ & $(-)$ & 46.5 \\
\hline & 2 & 125 & $2.8^{*}$ & 4.82 & $(-)$ & 0 \\
\hline & 3 & 62.5 & $4.95^{*}$ & 4.25 & $(-)$ & 0 \\
\hline \multirow{3}{*}{ MS-222 } & 4 & 250 & 2.5 & 5.26 & $(-)$ & 33.3 \\
\hline & 5 & 125 & 6.1 & 4.12 & $(-)$ & 0 \\
\hline & 6 & 62.5 & 13.4 & 2.18 & $(++)$ & 0 \\
\hline Control & & 0 & 0 & 0 & $(+++)$ & 0 \\
\hline
\end{tabular}

Each datum represents the mean \pm SEM of 15 fish/group. All chemicals are administered through aqueous exposure. ${ }^{*} \mathrm{P}<0.05$ related to MS-222 (Student's $t$-test)

Table (2): Effect of aquous exposure of Clarias gariepinus to Eugenol and Ms-222 on some serum parameters.

\begin{tabular}{|c|c|c|c|c|c|c|c|c|c|c|}
\hline Group & ALT & AST & Glucose & $\begin{array}{c}\text { T. } \\
\text { Protein }\end{array}$ & Albumin & Globulin & Creatinine & Urea & $\begin{array}{l}\text { Uric } \\
\text { acid }\end{array}$ & Calcium \\
\hline \multirow[b]{2}{*}{1} & 37 & 60.8 & 94 & 3.2 & 1.3 & 1.7 & 0.96 & 7.1 & 1.6 & $11.1 \pm$ \\
\hline & \pm 2.1 & $\pm 2.4^{*}$ & \pm 1.5 & $\pm 0.3^{*}$ & $\pm 0.13 *$ & \pm 0.2 & $\pm 0.1 *$ & $\pm 0.2 *$ & $\pm 0.17 *$ & $0.15^{*}$ \\
\hline \multirow{2}{*}{2} & 22 & 26.6 & 94 & 3.4 & 1.5 & 1.95 & 0.92 & 3.7 & 1.15 & 10.6 \\
\hline & \pm 1.9 & \pm 1.6 & \pm 1.3 & \pm 0.2 & \pm 0.22 & \pm 0.2 & \pm 0.17 & \pm 0.2 & \pm 0.13 & \pm 0.31 \\
\hline \multirow{2}{*}{3} & 21 & 26 & 96 & 3.5 & 1.38 & 2.1 & 0.85 & 3.13 & 1.12 & 10.1 \\
\hline & \pm 0.85 & \pm 1.1 & \pm 0.9 & \pm 0.3 & \pm 0.3 & \pm 0.3 & \pm 0.02 & \pm 0.2 & \pm 0.12 & \pm 0.27 \\
\hline \multirow{2}{*}{4} & 21.6 & 35.3 & 94.6 & 3.2 & 1.43 & 2.08 & 0.9 & 9.8 & 1.8 & 9.1 \\
\hline & \pm 0.8 & \pm 1.4 & \pm 0.9 & $\pm 0.3^{*}$ & $\pm 0.3^{*}$ & \pm 0.4 & $\pm 0.01 *$ & $\pm 0.5^{*}$ & $\pm 0.11^{*}$ &. \pm 0.32 \\
\hline \multirow[t]{2}{*}{5} & 22 & 28.6 & 92.7 & 3.5 & 1.27 & 1.94 & 0.86 & 5.8 & 1.28 & 9.96 \\
\hline & \pm 1.1 & \pm 1.3 & \pm 0.8 & \pm 0.2 & \pm 0.3 & \pm 0.2 & \pm 0.1 & \pm 0.15 & \pm 0.12 & \pm 0.28 \\
\hline \multirow[b]{2}{*}{6} & 21.3 & 24.3 & 95.6 & 3.5 & 1.6 & 1.93 & 0.89 & 5.1 & 1.22 & 9.4 \\
\hline & \pm 0.7 & \pm 0.7 & \pm 1.2 & \pm 0.2 & \pm 0.2 & \pm 0.2 & \pm 0.19 & \pm 0.2 & \pm 0.17 & \pm 0.12 \\
\hline \multirow{2}{*}{ Con } & 20.9 & 25.9 & 95.3 & 3.8 & 1.8 & 2.0 & 0.82 & 3.4 & 1.2 & 9.5 \\
\hline & \pm 1.5 & \pm 0.92 & \pm 0.7 & \pm 0.12 & \pm 0.17 & \pm 0.3 & \pm 0.14 & \pm 0.22 & \pm 0.1 & \pm 0.15 \\
\hline
\end{tabular}

Data expressed as the mean S.E.M. of 15 fish/group

$* \mathrm{P}<0.05$ relative to control (One-Way ANOVA).

and albumin (Table 2). Exposure of fish to MS$222(250 \mu \mathrm{g} / \mathrm{ml})$ resulted in significant increase in creatinine, urea and uric acid and decrease in total protein and albumin (Table 2). On the other hand, moderate and lower concentrations of both agents (125 and $62.5 \mu \mathrm{g} / \mathrm{ml}$ ) produced no significant alterations in comparison with the control non-treated group (Table 2).

Histopathological changes induced by eugenol and MS-222 in Clarias gariepinus. The gills of fish exposed to high concentrations $(250 \mu \mathrm{g} /$ $\mathrm{ml}$ ) of both eugenol and MS-222 showed congestion of the gills blood vessels (Fig.1). In addition, diffuse vacuolar degeneration and necrosis of the epithelium lining of the secondary lamellae of the gill filament of fish exposed to high concentrations $(250 \mu \mathrm{g} / \mathrm{ml})$ of both eugenol and MS-222 were observed

(Figs.2, 3). Hyperplasia of the epithelial lining the tertiary gill lamellae was observed in high doses (Fig. 4). Whereas, fish exposed to lower concentrations of both agents did not differ from those of control fish. Livers of fish exposed to $250 \mu \mathrm{g} / \mathrm{ml}$ of eugenol showed massive fatty change as well as necrosis. (Fig. 5). The liver of the fish exposed to $125 \mu \mathrm{g} / \mathrm{ml}$ eugenol showed moderate centrolobular vacuolar degeneration (Fig.6). While liver of fish exposed to $62.5 \mu \mathrm{g} /$ $\mathrm{ml}$ of eugenol showed mild degenerative changes (Fig. 7). There were no alterations in the livers of fish exposed to MS-222 at all concentration levels. Kidneys of fish groups 

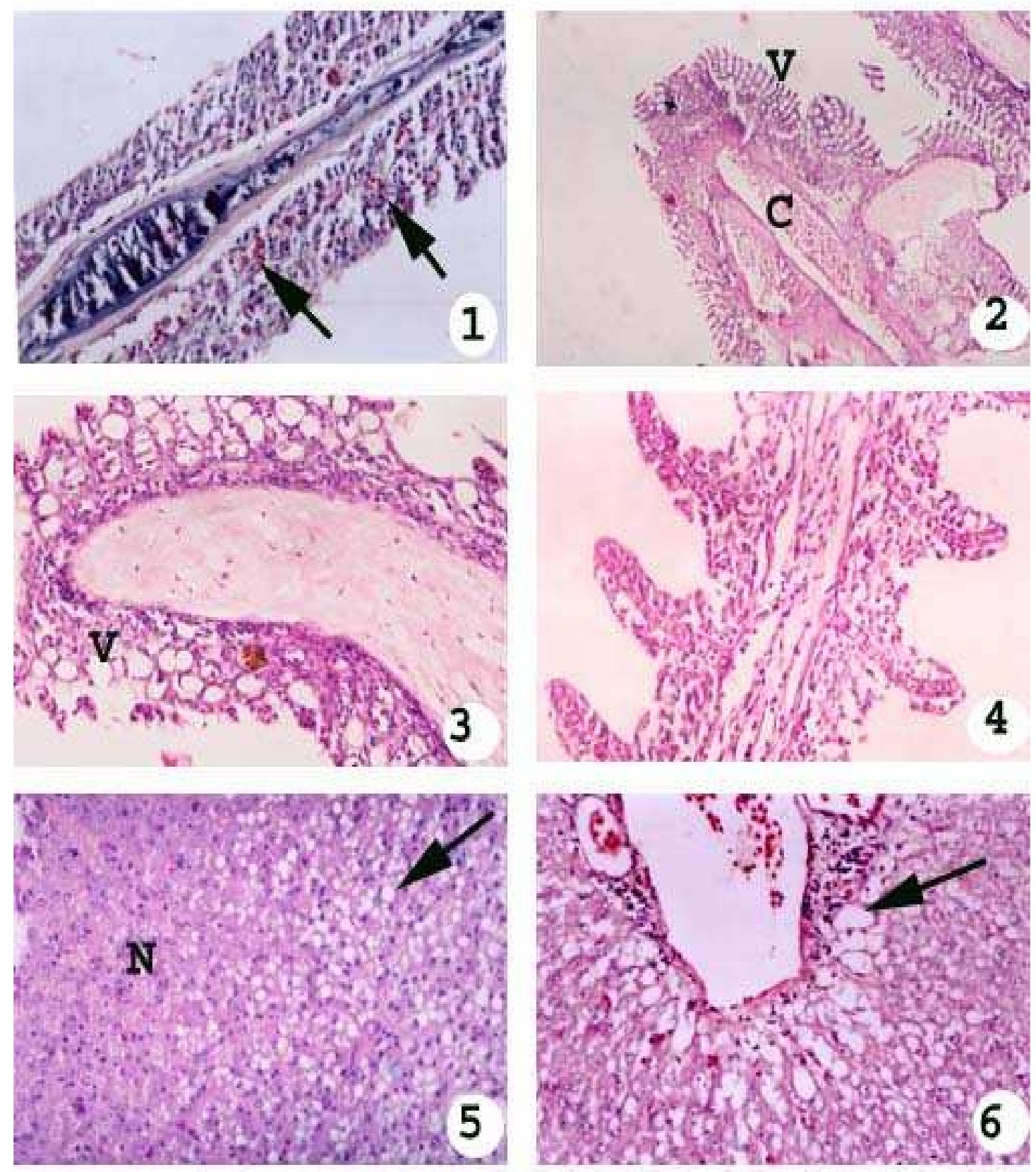

Fig. (1): Gill of group 1, showing congestion of gill's blood vessels. H\&E. X400.

Fig. (2): Gill of group 1, showing hyperplasia and vacuolation of the epithelium lining the secondary lamellae of the gill filament as well as congestion in the blood vessels H\&E. X 100.

Fig. (3): Gill of group 1, showing vacuolation of the epithelium lining the secondary lamellae of the gill filament. H\&E. X 400.

Fig. (4): Gills of group 1, showing hyperplasia of the epithelium lining the tertiary lamellae of the gill filament as well as congestion in the blood vessles $H \& E$. $X$ 400.

Fig. (5): Liver of group 1, showing vacuoles of different sizes and shape in hepatocytes suggesting fatty change (arrow) as well as necrosis (n). H\&E. X 400.

Fig. (6): Liver of group 3, showing moderate centrolobular vacuolation H\&EX400 

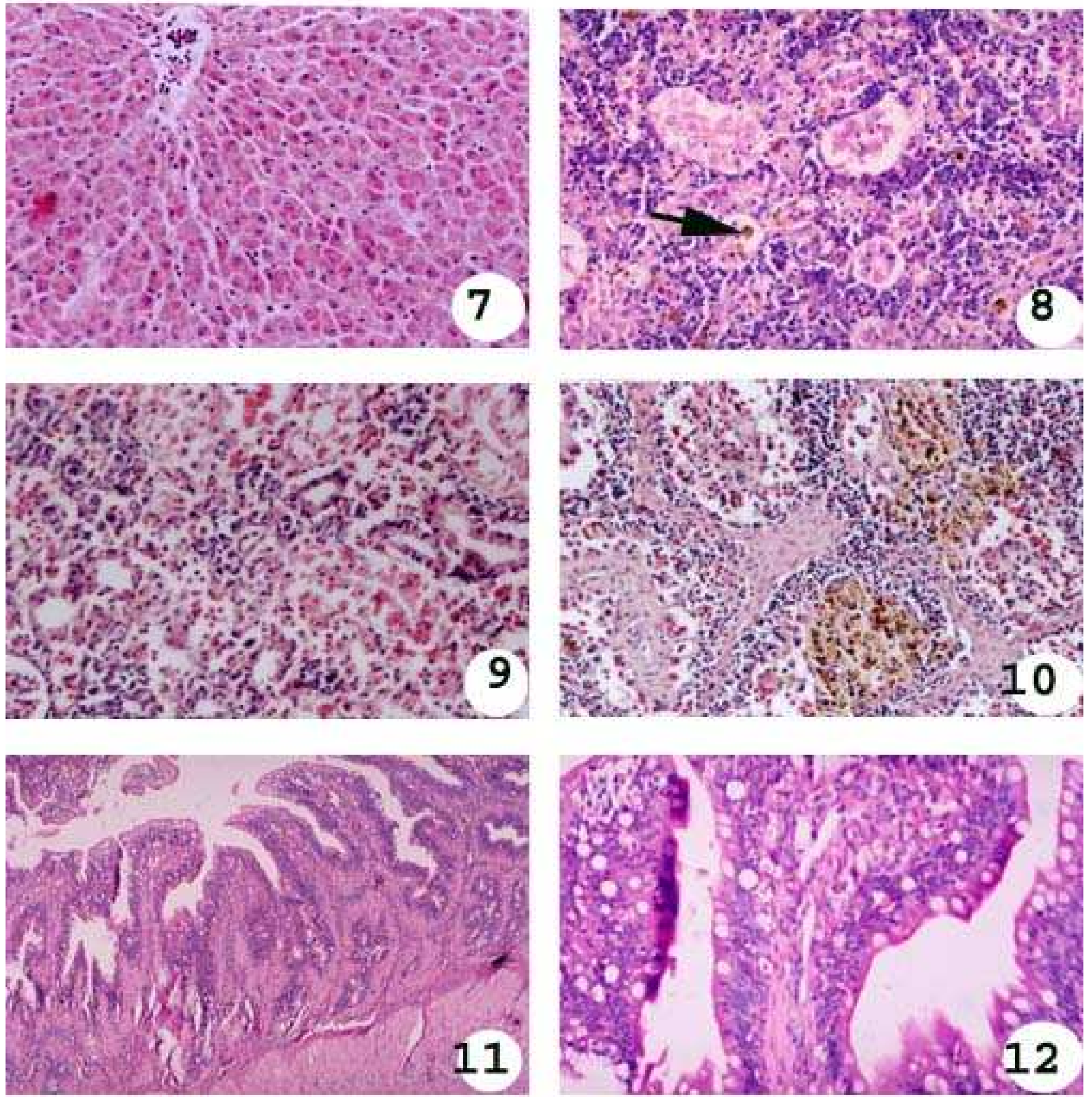

Fig. (7): Liver of group 3, showing mild degeneration. H\&E. x400.

Fig. (8): Kidney of group 1, showing degeneration and multifocal necrosis of renal tubules and hemosiderin pigments between the renal tubules. H\&E. $x 400$.

Fig. (9): Kidney of group 2, showing degeneration of renal tubular epithelium. H\&E. x 400.

Fig. (10): Spleen of group 1, showing deposition of hemosidrin pigment in macrophages or

free in the splenic tissue along with necrotic changes. H\&E. $x 400$.

Fig. (11): Intestine of group 1, showing mild catarrhal enteritis. H\&E. x 100.

Fig. (12): intestine of group 1, showing mild catarrhal enteritis. H\&E. $x 400$. 
exposed to high concentration $250 \mu \mathrm{g} / \mathrm{ml}$ of both agents showed degeneration and multifocal necrosis of renal tubules (Fig. 8). Hemosiderin pigments were seen between the renal tubules. In case of other concentrations, the kidney had mild degeneration in the renal tubules (Fig. 9). Both agents induced necrosis of spleen and deposition of hemosiderin pigment in the macrophage especially at high concentration (Fig. 10). Intestine in all groups had mild catarrhal enteritis (Figs. 11, 12).

\section{Discussion}

The present study demonstrated that eugenol, the major essential oil in clove has significant anesthetic activity as it resulted in complete loss of tail and escape reflexes of Clarias gariepinus at concentration levels of $31.2-250 \mu \mathrm{g} / \mathrm{ml}$. Induction period was very short and recovery was prolonged in a concentration-dependent manner. Our finding is compatible with that of (Sladky et al., 2001) who recorded more rapid induction and more prolonged recovery in fish (red pacu) exposed to eugenol, compared with those exposed to tricaine methanesulfonate. The loss in tail and escape reflex observed during anesthesia with eugenol at high and moderated concentration are in agreement with that reported by (Anderson et al., 1997) who found that concentrations of $20-40$ and $100-120 \mu \mathrm{g} / \mathrm{ml}$ induced light and heavy anesthesia in adult rainbow trout, respectively. The mechanistic action of eugenol anesthesia is not understood. Eugenol has been demonstrated as competitive neuromuscular blocking agent and neostigmine restored its effect in vitro in rat phrenic nervediaphragm preparation (Ghelardini et al., 2001 and Ingvast-Larsson et al., 2003). In addition, eugenol has been recorded to increase the sleeping time in rats (Sousa et al., 1990) and has analgesic and anti-inflammatory properties Sharma, (1994). Moreover, methyleugenol induced a large amount of slow wave activity in EEG of rats Sell and Carlini, (1976). Further experiments are designed to investigate the mechanism of eugenol anesthesia in fish. The mild increase in serum level of ALT andthe marked increase of AST following eugenol exposure may be attributed to increase synthesis or decrease catabolism of these enzymes Rouiller, (1964) or because of a direct damage of hepatic cells resulting in escape of these enzymes into the plasma Doxy, (1971). On the basis of the histopathological examination of the liver, it appears that the necrosis, massive fatty and degenerative changes that were observed may explain the increase in the levels of such enzymes. The significant increases of serum creatinine, urea and uric acid levels of fish exposed to eugenol or MS-222 indicated that glomerular filteration rate was reduced as a result of impaired kidney function Close, (1986) and this was demonstrated by degeneration and focal necrosis of renal tubules of examined fish. The decrease in total protein and albumin may be attributed to the recorded liver damage and impaired kidneys functions. The normal glucose levels observed after fish exposure to both agents are compatible with that reported by (Holloway et al., 2004) who could not find any significant differences in glucose and cortisol levels of trout euthanized by eugenol or MS-222.

The blood vessels congestion of gills and necrosis of the epithelium lining the gill filament may be explained by the criteria of such agents and species used in this study, since these chemicals are absorbed and excreted predominantly via the gills and also, scaleless, well-vascularised skins which help greatly in the gill injury. Our findings are in accordance with Afifi et al, (2001) who described necrosis of gill epithelium lining the secondary lamellae of Asian sea bass, Lates Calcarifer, exposed to clove oil. These findings also may be supported by the data of Sladky et al, (2001) who found that anesthesia induced with MS-222 or eugenol contributed to hypoxemia, and respiratory acidosis in red pacu since both agents decreased the venous-arterial $\mathrm{PO} 2$ and increased the $\mathrm{PCO} 2$ and accompanied by a decrease in $\mathrm{pH}$ and respiratory acidosis. Our findings revealed the presence of hemosiderin pigment, which is indicative for hemorrhage and hemolysis. We attribute that hemorrhage to the severe congestion observed in gills and other organs, In conclusion, it appears that eugenol at lower and medium concentration could produce an anesthesia characterized by rapid induction, and rational recovery without significant changes in tissues and blood chemistry. Care should be taken when using high concentrations of eugenol as ventilatory failure may occur.

\section{References}

Afifi, S. H.; Al-Thobaiti, S. and Rasem, B. M. (2001): Multiple exposures of Asian sea bass (Lates Calcarifer, Centropomidae) to clove oil: a histopathological study. J. Aquacul. 16: 131-138.

Anderson, W. G.; McKinley, R. S. and Colavecchia, M. (1997): The use of clove oil as an anaesthetic for rainbow trout and its effects on swimming performance. North Am. 
J. Fisher. Manag. 17: 301-307.

Bancroft, S. and Stevens, R. (1990): Theory and practice of histological techniques. $3^{\text {rd }}$ ed. Churchill, Livingstone, New York.

Bell, G. R. (1967): A guide to the properties characteristics and uses of some general anesthetics in fish. Fisheries Res. Board of Canada Bull., 148: 11.

Blaxter, J. H. S. and Tytler, P. (1978): Physiology and function of the swim bladder. Adv. .Comp. Physiol. Biochem. 7: 311-367.

Booth, N. H. and McDonald, L. E. (1986): Veterinary pharmacology and therapeutics. $6^{\text {th }}$ ed.. Iowa State Univ Press/Ames, pp. 203.

Close, E. H. (1986): Veterinary Clinical Pathology, $4^{\text {th }}$ ed. Saunder Company, Philadelphia.

Doumas, B. (1971): Colorimetric determination of serum albumin. Clin. Chem. Acta, 400-403.

Doumas, B. T. and Biggs, H. G. (1972): Determination of serum globulin. In: G. R. Cooper (ed.), Stander Methods of Clinical Chemistry. New York Academic Press, pp. 230236.

Doxy, D. L. (1971): Veterinary Clinical Pathology. $1^{\text {st }}$ ed. London, pp. 556.

Ghelardini, C.; Galeotti, N. and Mazzanti, G. (2001): Local anesthetic activity of monoterpenes and phenylpropanes of essential oils. Planta Med. 67 (6): 564566.

Gundler, E. and Kin, J. (1972): Rapid colorimetric determination of calcium in biological fluids with methyle thymol blue. Am. J. Clin. Pathol., 58: 376-382.

Henry, R. J. (1974): Colorimetric method for determination of serum total protein. Clinical Chemistry Harper and Row Publishers, New York. pp. 181.

Henry, R. J. (1979): Colorimetric method for determination of serum creatinine. Clin Chem, principles and technique $2^{\text {nd }}$ ed. Harper and Row Publishers, pp. 525.

Holloway, A. C.; Keene, J. L.; Noakes, D. G and Moccia, R. D. (2004): Effects of clove oil and MS-222 on blood hormone profiles in rainbow trout Oncorhynchus mykiss, Walbaum. Aquacul.Res., 35: 1025-1031.

Ingvast-Larsson, J. C.; Axen, V. C. and Kiessling, A. K.
(2003): Effects of isoeugenol on in vitro neyromuscular blockade of rat phrenic nerve-diaphragm preparations. Am. J. Vet. Res., 64 (6): 690-693.

Innes, W. T. (1966): Exotoxin aquarium fishes. $19^{\text {th }}$ ed. Aquarium in corporated, New Jersey.

Mattson, N. S. and Riple, T. H. (1989): Methomidate, a better anaesthetic for cod (Gadus morhua) in comparison with Benzocaine, MS-222, chlorobutanol, and phenoxyethanol. Aquacul., 83: 89-94.

Meepagala, K. M.; Sturtz, G.; and Wedge, D. E. (2002): Antifungal constituents of the essential oil fraction of Artemisia dracunculus L. Var. dracunculus. J. Agric. Food Chem., 20; 50 (24): 6989-92.

Miele, M.; Ledda, B.; Falugi, C. and Mazzei M. (2001): Methyleugenol and eugenol variation in Ocimum basilicum $\mathrm{cv}$. Genovese gigante grown in greenhouse and in vitro. Boll. Soc. Ital. Biol., 77: 43-50.

Patton, C. and Grouch, S. (1977): Enzymatic determination of urea. Anal. Chem., 49: 464-469.

Reitman, S. and Frankel, S. (1957): A colorimetric method for the determination of serum glutamic oxaloacetic and glutamic pyruvic transaminase. Am. J. Clin. Pathol., 28: 56-63.

Rouiller, C., (1964): The liver morphology, biochemistry and physiology. New York, Academic Press. pp. 335-476.

Sell, A. B. and Carlini, E. A., (1976): Anesthetic action of methyleugenol and other eugenol derivatives. Pharmacol., 14: 367-77.

Sharma, J. N., (1994): Suppressive effects of eugenol and ginger oil on arthritic rats. Pharmacol., 49: 314-318.

Sladky K. K.; Swanson C.R.; Stoskopf, M. K.; Loomis, M.R. and Lewbart, G. A., (2001): Comparative efficacy of tricaine methanesulfonate and clove oil for use as anesthetics in red pacu (Piaractus brachypomus). Am. J. Vet. Res., 62: 337-42.

Sousa, M. B.; Ximenes, M. F.; Mota, M. T.; Moreira, L. F. and Menezes, A. A. (1990): Circadian variation of methyleugenol anesthesia in albino rats. Braz.J. Med. Biol. Res., 23 (5): 423-425.

Virapin, P., (1968): Dental anesthesia: Was one can find eugenol. Chir. Dent. Fr., 24: 38 (4): 34-5. 
VOL. 15 , No. 2 